\title{
Communication
}

[Comunicação]

\section{Bilateral ventricular myocardial dysplasia in a Shar-Pei dog}

\author{
[Displasia miocardial ventricular bilateral em um cão Shar-Pei]
}

\author{
N.M. Ocarino, E.F. Nascimento, J.D.G. Paniago, R. Serakides ${ }^{*}$ \\ Escola de Veterinária - Universidade Federal de Minas Gerais \\ Avenida Presidente Antônio Carlos, 6627 \\ 30.161-970 - Belo Horizonte, MG
}

Dysplasia of the myocardium, also known as arrhythmogenic right ventricular dysplasia (ARVD), arrhythmogenic right ventricular cardiomyopathy (ARVC) or arrhythmogenic right ventricular dysplasia/cardiomyopathy (ARVD/C) (Basso et al., 2004; Harvey et al., 2005; Noszczyk-Nowak and Nowak, 2009) is a myocardial disease and an important cause of sudden death in humans, but has rarely been described in animals (Harvey et al., 2005).

It is characterized by structural abnormalities in the myocardium that prevail in the right ventricle and involve the gradual substitution of myocardial cells by adipose cells and cells of fibrous connective tissue (Noszczyk-Nowak and Nowak, 2009). The replacement extends from the epicardial surface towards the endocardium (Basso et al., 2004). The clinical signs of ARVD may include ventricular arrhythmias, syncope, heart failure or sudden death, or the animal can be asymptomatic (Hyun and Filippich, 2006).

In human medicine, as in veterinary medicine, cases of ARVD are observed in the free wall of the right ventricle (Fox et al., 2000; Corrado et al., 2001; Fernandez del Palacio et al., 2001). In dogs, ARVD is a variant of dilated cardiomyopathy, which affects Boxer dogs and large and giant breed dogs as well as cats (Basso et al., 2004; Maxie and Robinson, 2007). There is only one report of ARVD in a Siberian Husky (Fernandez del Palacio et al., 2001).
A 5-year-old female Shar-pei dog was submitted to a necropsy following sudden death after physical exercise. The dog's owner reported that the animal was always tired after physical exercise. Macroscopically, the size and form of the heart were normal. However, the myocardium of the free walls of the left and right ventricles were intensely pale (Fig. 1A). The liver and kidneys were strongly hyperemic. No macroscopic changes were observed in the other organs.

Fragments of the heart and the other organs were sent for histopathological examination. The tissue samples were fixed in $10 \%$ buffered formalin, routinely processed into paraffin blocks and cut into 4 - $\mu$ m-thick sections. For the histopathological evaluation, the sections were stained with hematoxylin and eosin (H\&E) stain plus Masson's trichrome stain. The microscopic examination of the myocardium of the right and left ventricles revealed severe infiltration by individual cells and small aggregates of welldifferentiated adipocytes (Fig. 1B). There was multifocal moderate atrophy (Fig. 1C) and degeneration of the remaining cardiomyocytes, as well as regionally discrete interstitial fibrosis. The liver and kidneys showed intense congestion. No microscopic changes were observed in the other organs. These histological findings are consistent with bilateral ventricular myocardial dysplasia.

Recebido em 9 de julho de 2010

Aceito em 6 de abril de 2011

*Autor para correspondência (corresponding author)

E-mail: serakidesufmg@gmail.com 


\section{Ocarino et al.}
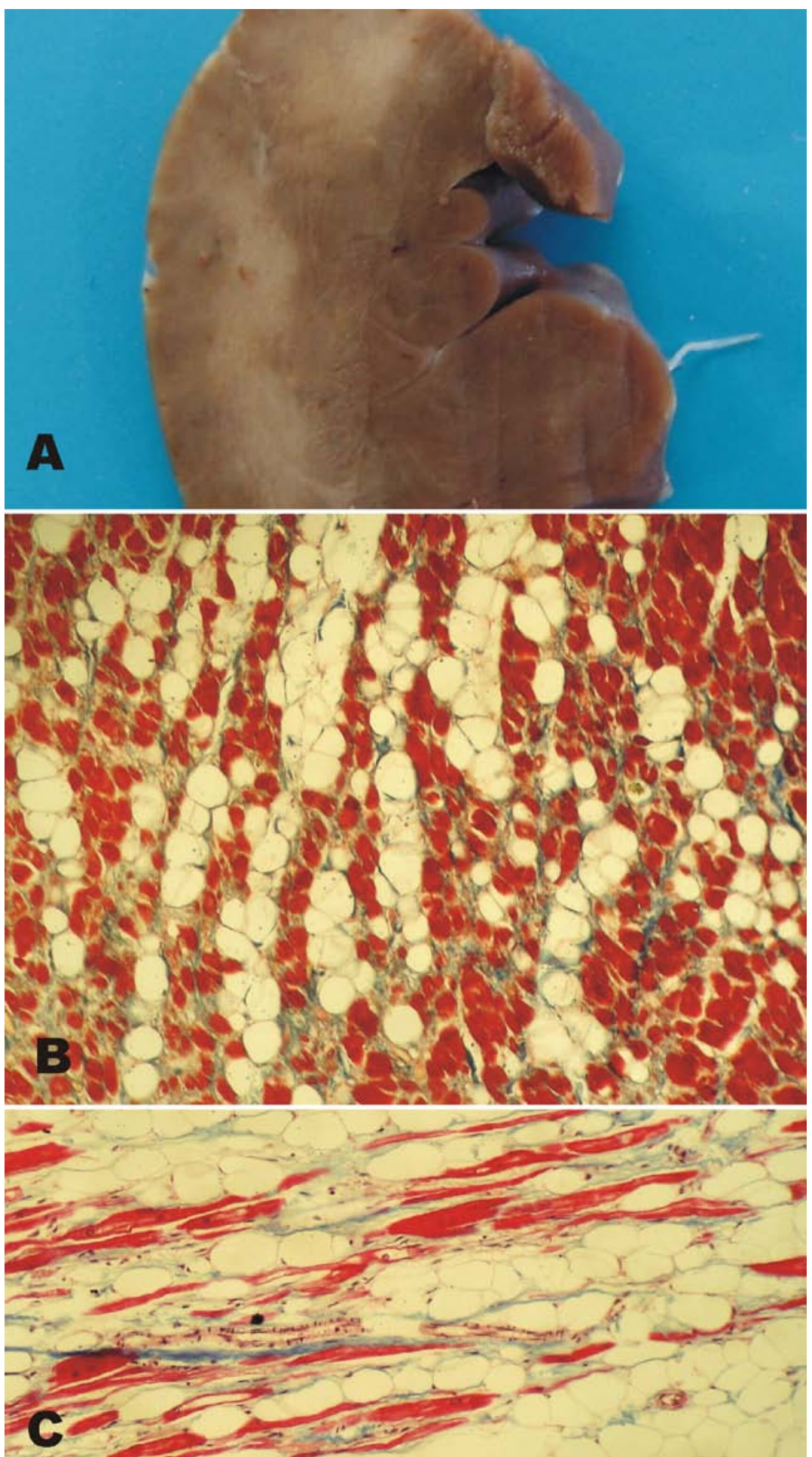

Figure 1. A. Heart, dog. The myocardium of the free wall of the left ventricle is intensely pale. B. The myocardium of the left ventricle with severe infiltration by individual cells and small aggregates of welldifferentiated adipocytes (Masson's trichrome, 50×). C. The myocardium of the left ventricle showing multifocal moderate atrophy and degeneration of the remaining cardiomyocytes (Masson's trichrome, $75 \times)$. 
There are two variants of myocardial dysplasia: fatty and fibrofatty. The fatty form consists of multifocal regions with adipocyte replacement within the ventricular wall accompanied by a mild interstitial fibrosis. The fibrofatty form is characterized by focal and diffuse regions of myocardial replacement by adipose tissue and marked fibrosis (Basso et al., 2004). In these cases, the myocardial dysplasia was the fatty form; we observed adipocyte replacement within the myocardium accompanied by mild interstitial fibrosis.

The pathogenesis of ARVD is largely unknown, but it is thought to be transmitted as an autosomal dominant trait in humans and Boxer dogs. Two mutations have been identified in the cardiac ryanodine receptor 2 gene (ARVD2) and the desmoplakin gene (ARVD8) (Basso et al., 2004). The loss of right ventricular myocardium with replacement by fat or fibrofatty tissue is the pathological hallmark of human ARVD (Thiene et al., 1997). In veterinary medicine, cases of ARVD are observed in the free wall of the right ventricle. Occasionally, the left ventricle may also be involved (Basso et al., 2004) but that has only been observed in Boxer dogs up to this point. To the best of our knowledge, this is the first reported case of ventricular myocardial dysplasia in a Shar-Pei dog, and it involved both the right and left ventricles.

Keywords: dog, dysplasia, heart

\section{RESUMO}

Um cão Shar-pei de cinco anos de idade foi encaminhado para exame de necropsia com histórico de morte súbita. Ao exame macroscópico foram observadas, no coração, áreas pálidas extensas envolvendo o miocárdio do ventrículo direito e esquerdo. Ao exame histológico foi observada infiltração intensa de células adiposas bem diferenciadas no miocárdio de ambos os ventrículos associada à moderada atrofia e degeneração de cardiomiócitos. Os achados microscópicos foram compatíveis com diagnóstico de displasia miocardial ventricular bilateral.

Palavras-chave: cão, displasia, coração

\section{REFERENCES}

BASSO, C.; FOX, P.R.; MEURS, K.M. et al. Arrhythmogenic right ventricular cardiomyopathy causing sudden cardiac death in boxer dogs: a new animal model of human disease. Circulation, v.109, p.1180-1185, 2004.

CORRADO, D.; BASSO, C.; THIENE, G. Sudden cardiac death in young people with apparently normal heart. Cardiovasc. Res., v.50, p. 399-408, 2001.

FERNÁNDEZ DEL PALACIO, M.J.; BERNAL, L.J.; BAYÓN, A. et al. Arrhythmogenic right ventricular dysplasia/cardiomyopathy in a Siberian husky. J. Small Anim. Pract., v.42, p. 137-142, 2001.

FOX, P.R.; MARON, B.J.; BASSO, C. et al. Spontaneously occurring arrhythmogenic right ventricular cardiomyopathy in the domestic cat: a new animal model similar to the human disease. Circulation, v.102, p.1863-1870, 2000.
HARVEY, A.M.; BATTERSBY, I.A.; FAENA, M. et al. Arrhythmogenic right ventricular cardiomyopathy in two cats. J. Small Anim. Pract., v.46, p.151-6, 2005.

HYUN, C.; FILIPPICH LJ. Molecular genetics of sudden cardiac death in small animals - a review. Vet. J. , v.172, p.39-50, 2006.

MAXIE, G.M.; ROBINSON, W.F. Cardiovascular system In: MAXIE, G.M. Jubb, Kennedy and Palmer's pathology of domestic animals, 5.ed. Philadelphia: Elsevier, 2007. v.3, p.48-49.

NOSZCZYK-NOWAK, A.; NOWAK, $\mathbf{M}$. Arrythmogenic right ventricle dysplasia in a boxer dog: a case report. Bull. Vet. Inst. Pulawy, v.53, p.541-545, 2009.

THIENE, G.; BASSO, C.; DANIELI, G. et al. Arrhythmogenic right ventricular cardiomyopathy. A still underrecognized clinic entity. Trends Cardiovasc. Med., v.7, p.84-90, 1997. 